\title{
Review
}

\section{Seed vigor testing: an overview of the past, present and future perspective}

\author{
Julio Marcos-Filho* \\ University of São Paulo/ESALQ - Dept. of Crop Science, \\ C.P.09 - 13418-900 - Piracicaba, SP - Brazil. \\ ${ }^{*}$ Corresponding author <juliomarcos.1@usp.br> \\ Edited by: Paulo Cesar Sentelhas
}

Received January 07, 2015

Accepted March 05, 2015

\begin{abstract}
The assessment of seed vigor has many important implications to the seed industry as a basic monitoring of seed physiological potential during different phases of seed production and a support for strategic decisions regarding the selection of high quality seedlots to meet the consumer demand. The potential attributes of seed vigor as a fundamental physiological seed characteristic and its association with field stand establishment and crop productivity has been worldwide recognized from the 1960s onward. This led to the diversification of research approaches involving the synchronization of different physiological characteristics and events that determine the potential for high performance during seed storage and after sowing. The basic objective of vigor testing is to provide a consistent identification of differences in physiological potential among seedlots of commercial value and this represents a more sensitive parameter than the germination test. There are various procedures to assess seed vigor including those that directly or indirectly evaluate seed metabolic state or identify seed tolerance to specific stress(es). At the same time, in more recent years, new knowledge has come from molecular biology, biotechnology, biophysics and seed and seedling imaging analyses; these approaches has been important complements to traditional seed research.. This text has the purpose to emphasize the role of Brazilian research in seed vigor, whose competence is internationally recognized, and to provide an overview of the evolution of knowledge also attempting to highlight events that contributed to the advancement of research on the subject.

Keywords: Seed physiology, seed analysis, quality control, physiological potential
\end{abstract}

\section{Introduction}

Field establishment of grain, vegetable, fruit and forage crops is usually performed with the direct or indirect use of seeds, and it is estimated that approximately $80 \%$ of economically significant crops are planted in that way. As a result, rapid and uniform emergence of vigorous seedlings of the desired cultivar is key events to ensure high plant performance that affects uniformity of development, yield and quality of the harvested product. These factors emphasize the importance of selecting high quality seed lots that are available in sufficient quantities to meet demand.

The evaluation of germination and the identification of seed lots of high performance is an important initiative towards successful crop production, and consequently information from seed laboratories must accurately detect differences in physiological potential among tested seed lots. The performance of seeds after sowing or during storage demonstrates whether the potential identified by appropriate laboratory tests was achieved and how adequate were the procedures used to this evaluation.

Laboratory test results are more easily reproduced in the field when the environment is favorable for emergence and initial seedling growth. However, the use of other approaches to estimate seed performance under less favorable field conditions is required since deviations in ideal field conditions are common. To meet this demand, research in Seed Technology has focused on identifying various aspects associated with loss in seed physiological potential. Special attention has been directed to this subject from the time man discovered the possibility of using seeds to multiply desired plant species. This is not a complete surprise because seeds developed under favorable environmental conditions and managed properly from physiological maturity to commercialization constitute a solid basis for improved stand establishment in the field and high crop productivity.

Factors influencing seed physiological potential include germination (viability) and vigor, which govern the theoretical capacity of seeds to express their vital functions under both favorable and unfavorable environmental conditions. The concept of suboptimal conditions varies according to species, cultivar and plant development stage, but usually includes temperature, water availability, soil characteristics, plant protection and management practices.

Maximum physiological potential is achieved close to seed maturity and just after this stage, seeds become prone to deterioration depending on harvest time, environmental conditions, and procedures adopted for seed drying, processing and storage. The most obvious manifestation of initial seed aging is the decline in germination speed of viable seeds followed by a decrease in seedling size, and an increased incidence of abnormal seedlings (although the primary root protrusion rate should remains high). The low germination rate has been associated to early signs of membrane disorganization 
while the occurrence of seedling abnormalities (in the final stages of deterioration) is attributed to the significant death of tissues in different seed parts, particularly in meristematic tissues.

Various researchers have tried to elucidate the mechanisms involved in seed deterioration and also the possible transformations that can provoke differences in seed performance. Matthews (1985), Ganguli and Sen-Mandi (1990), Basavarajappa et al. (1991), Das and Sen-Mandi (1992), and McDonald (1999), among others, showed evidence that seed exposure to unfavorable environmental conditions might cause serious degenerative changes in metabolic activities. These include changes in mitochondria synthesis and activity, protein denaturation, decreases in storage reserves, increases in free fatty acids and reducing sugars levels, decreased enzyme activity, and protein and RNA syntheses. Most of these events are triggered by disorganization and loss of integrity of the cell membrane system caused by lipid peroxidation thus reducing seed physiological potential.

Unfortunately, today there is no universally accepted single test for assessing seed physiological potential of a given species or group of species to achieve predetermined objectives. For this reason, research on seed testing and the identification of factors that affect seed performance have been considered priorities among seed scientists in comparison to other quality attributes.

\section{Historical context}

Seed physiology, especially seed germination and its influence on plant performance, have been of central interest to humans since the establishment of Agriculture when men discovered the potential use of seeds for the multiplication of plants, around 10.000 B.C.

The evaluation of seed physiological potential is well documented in the literature beginning with observations from Nobbe, in 1876 that proposed procedures for a germination test. During the 1940's, the first studies for the determination of seed viability by the tetrazolium (TZ) test were reported, which is currently one of the most commonly used seed tests in Brazil. However, both germination and $\mathrm{TZ}$ viability tests might not be closely related with field seedling emergence when environmental conditions are not favorable. For this reason, information provided by these two tests need to be supplement from results of more accurate determinations.

The term 'seed vigor' was introduced by F. Nobbe in 1876, in his "Handbuch der Samenkunde". In 1911, Hiltner and Ihssen used the term triebkraft to imply "driving force" and "shooting strength" of germinating seedlings, to highlight seeds that produced seedlings with longer roots in comparison to those from "weaker" seeds from the same lot. The early days of research on seed vigor and its evaluation included studies conducted by Hiltner and Ihssen (AOSA, 1983) who developed the brick grit test, Fick and Hibbard (1925) the electrical conductivity, Stahl (1931) that evaluated speed of germination and the first observations about the cold test (Alberts, 1927; Tatum and Zuber, 1943).

The 1930's faced an increasing acceptance in the United States of the term "germination energy" to express speed of germination. However, during this period, there was not sufficient interest by researchers or seed technologists to advance these studies. During the first half of the twentieth century, relatively little was added to the knowledge base on the evaluation of the physiological potential, except for the development of the tetrazolium test by Lakon in the 1940s, as reported by França-Neto et al. (1998).

It was not until 1950, however, at the International Seed Testing Association (ISTA) Congress held in Washington, D.C. that this seed quality attribute was focused on. The identification of vigor as a component of seed physiological potential, independent from seed germination, gained considerable credence as a separate and essential component of seed quality. At that time, Franck (1950), during that ISTA meeting, proposed differentiating the terminology and objectives of standard germination tests (performed with artificial substrates under optimum environmental conditions) prevailing in Europe from tests performed under field conditions or related to the percentage of seedling emergence (following methodology used in the USA). It was therefore proposed and accepted a new term, vigor tests, to better express the seed physiological potential, mainly under suboptimal conditions.

Since then, a change in the course on research became evident where approaches and efforts have focused on creating or improving methods for vigor testing and identifying the effects of factors that affect seed performance. Currently, vigor tests are tools routinely used in-house seed quality control programs, especially for grain and vegetable crops. However, during the first years after this 1950 ISTA Congress, less attention was given in the United States to discrepancies in germination test results or to the importance of vigor to assess seed physiological potential. The main view was the idea that this question was primarily an European concern (McDonald, 1993).

During the 1960s, research on the evaluation of vigor and its influence on seed performance were intensified, an effort that also stimulated significant research on other aspects of Seed Physiology. These included attempts to establish a definition and a universally accepted concept of seed vigor. Contributions on the improvement of the tetrazolium test, the development of the accelerated aging test, and the creation of the electrical conductivity test, were pioneer initiatives and a substantial volume of research also led to the training of a new generation of seed scientists. As emphasized by Woodstock (1973), from the 1960s onward, vigor was recognized by technologists and the seed industry as an important physiological seed characteristic. Research became more frequent and new information generated, documented and quickly disseminated. 
As the seed maturation process became better known, seed vigor assumed yet another level of importance. This led to further research on seed deterioration and the need to better understand how this affected the performance of seedlots during storage. In general, with the advancement of knowledge about the main events of the aging process, studies focusing on the integrity of cell membranes, lipid peroxidation and the cytoplasm glassy state have gained increasing prominence. Important contributions to this knowledge were provided by Priestley (1986), Wilson and McDonald (1986), and McDonald (1999).

The progress of knowledge about seed vigor, maturation and deterioration resulted in a diversification of research approaches, leading to a chain reaction and synchronization of different themes closely associated with seed physiological potential: the activity of repair mechanisms, recalcitrance in seeds, desiccation tolerance, and concept, techniques and effects of priming (incorrectly considered as seed "invigoration"). Consequently, the recognition of the significance and importance of seed vigor, its correct evaluation and influence on seed performance can be considered the main factor impacting the development of Seed Physiology research, a situation that persists today. These topics remain the major contents of scientific and technical seed journals, presentations in meetings, congresses, seminars, and books about seeds and represent the primary interests of seed companies and consumers when asked about their research priorities.

\section{Concepts}

McDonald (1993) reported that Franck (1950) during the ISTA Congress, established the ISTA Biochemical and Seedling Vigor Committee and challenged it with two principal objectives: i) define seed vigor, and ii) develop standardized vigor test methods. The first step was to develop an accepted definition because, without a precise understanding about what seed vigor was, the possibility of creating reliable methodology to assess this quality parameter would be very difficult if not impossible.

From the beginning, seed vigor could not be characterized as a single defined physiological process such as germination or deterioration. In fact, some suggested that seed vigor was so complex that it could not be reasonably defined and that this parameter could only be better understood under the framework of a concept (McDonald, 1993). In this way, the first attempt to establish a definition was to consider seed vigor as a "sum total of seed attributes, which favor stand establishment under favorable conditions" (Isely, 1957). This shows that the first real proposal for a seed vigor concept only raised seven years after the Washington D.C. ISTA Congress.

The initial concepts of vigor focused on the advantages over the germination and tetrazolium tests with respect to the identification of seed lots able to achieve rapid and uniform emergence and stand establishment under less favorable environmental conditions as mentioned by Sharf (1953) and others at that time. This was the prevailing approach in the first concepts proposed by different members of the Association of Official Seed Analysts - AOSA/USA, while Delouche and Grabe (1958) referred to vigor as a "seed physiological resistance". With the evolution of knowledge, there were other connotations like that of Woodstock (1965) emphasizing that seed vigor was a condition of good health and natural robustness associated with rapid and complete germination under a wide range of environmental conditions. This was the first time that the expression "wide range" was utilized instead of "favorable or unfavorable" environmental conditions.

Some years later, Pollock and Roos (1972) assumed that seed vigor might be considered as a potential for seedling establishment in the field and the same idea was supported by various seed technologists. Those new approaches and the comments from TeKrony (2003) constituted the foundation for the current concepts of seed vigor, i.e.: "seed vigor is the sum of all those properties which determine the potential for rapid, uniform emergence, and development of normal seedlings under a wide range of field conditions" (AOSA, 1983; Baalbaki et al., 2009), and "seed vigor is the sum of those properties that determine the activity and performance of seed lots of acceptable germination in a wide range of environments; a vigorous seed lot is one that is potentially able to perform well under environmental conditions which are not optimal for the species" (ISTA, 2014). The importance of considering seed vigor as a "potential for rapid and uniform seedling emergence" and of seed performance under a "wide range of environmental conditions" are illustrated on Figures 1 and 2.

These current accepted concepts do not include the possible persistence of the effects of seed vigor throughout the plant development cycle persisting until yield. It may well be that the emergence of vigorous seedlings can result in high crop productivity because of rapid and uniform stand establishment. Moreover, the term vigor cannot be identified as a single seed physiological process, but usually lead to improved

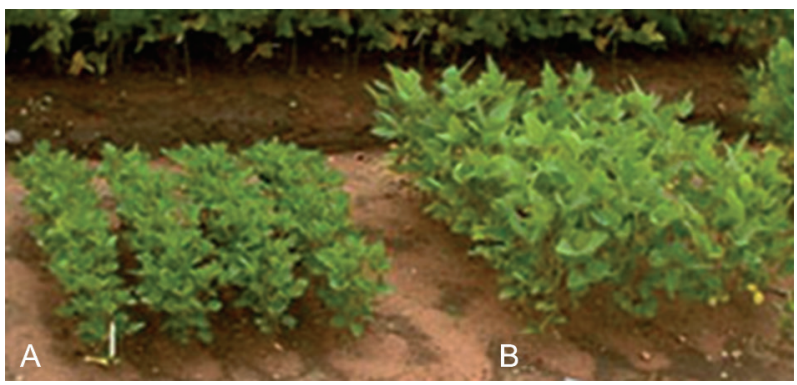

Figure 1 - Initial development of soybean seedlings of the same age from a lower (A) and higher (B) vigor seedlots, showing clear difference in performance. Photo: Dr. José B. França-Neto, Embrapa/Soja, Brazil. 


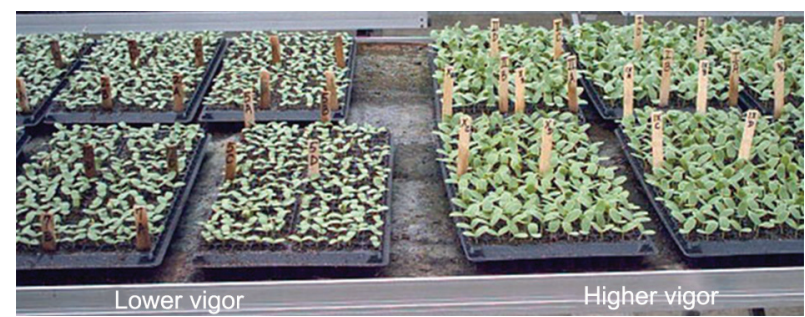

Figure 2 - Melon seedling emergence from two seedlots with differences in vigor when exposed to thermal stress after sowing. (Marcos-Filho et al., 2006). Just after sowing seeds were exposed to $18{ }^{\circ} \mathrm{C}$ for three days and then kept at $25{ }^{\circ} \mathrm{C}$ for subsequent germination. Seedlings from lower vigor seeds were adversely affected by suboptimal temperature in contrast with those of higher vigor.

seedling emergence or greater storability. Seed vigor can be considered an abstract characteristic and this expression was probably introduced to "fill a slot" owing to the absence of effective parameters to elucidate frequent questions about seed performance under less favorable conditions.

In fact, seed vigor is an interaction of characteristics that also could be considered as independent attributes of physiological potential such as speed of germination, seedling growth, ability to germinate above or below optimal temperatures, and other aspects of tolerance to stresses. This situation hinders the establishment of a precise definition, since many factors are involved in the composition and manifestation of seed vigor; perhaps for this reason, few scientists have either tried or achieved success in attempts to improve the concept towards a definition because it is easier to understand vigor main effects than defining it.

\section{Seed Vigor Testing}

The basic objective of seed vigor testing is to provide a precise identification of important differences in physiological potential among seed lots of commercial value, mostly those of similar germination percentage, aiming to identify lots of higher probability to perform well after sowing and/or during storage. It must be considered, therefore, that the requirements of an efficient vigor test include high sensitivity to differences in physiological potential not detected by viability tests and the ability to rank lots according to their performance potential.

Thus, it is necessary to identify high and low vigor seed lots in a comparable way to field seedling emergence. Figure 3 highlights the relationship between seed vigor and germination losses overtime as deterioration progresses. Consequently, a consistent evaluation of seed physiological potential involves both the use of standardized procedures and the correct interpretation of the meaning and scope of results.

Vigor testing is a more sensitive measure of seed physiological quality and it is understandable and

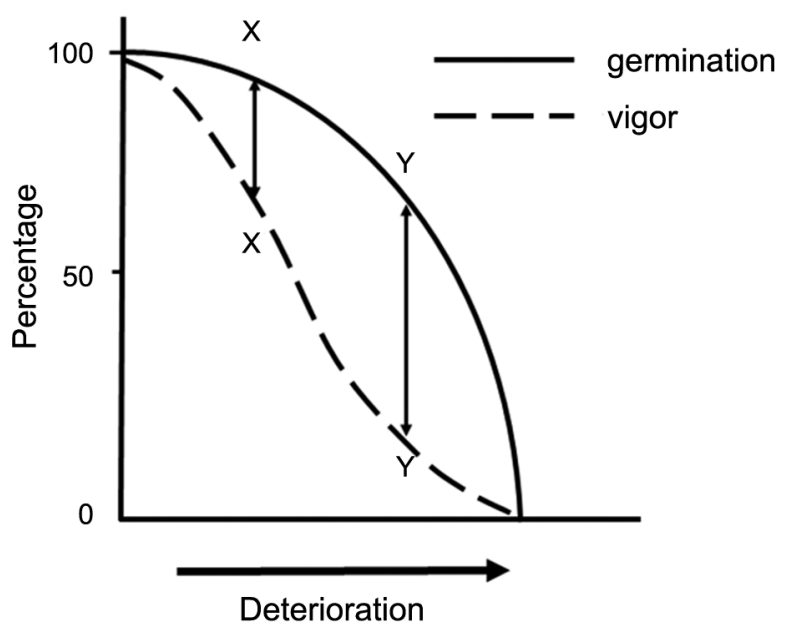

Figure 3 - Relationships between seed germination and vigor in association to the progress of deterioration $d$. The $X$ and $Y$ points on the germination and vigor curves correspond to different seed lots and illustrate the increasing difference between germinability and vigor as deterioration progresses. (Adapted from Delouche and Caldwell, 1960). A high quality seed lot (X) that is less deteriorated will show relatively small difference in results from germination and vigor tests. However, a lower physiological quality seed lot $(\mathrm{Y})$ with higher deterioration level will have higher germination performed under optimum conditions, but extremely low vigor.

natural that the evaluation of seed vigor requires more rigorous control of test variables and interpretation criteria to obtain consistent results. It is essential that seed analysts, technologists and consumers understand that vigor tests were not designed to predict the exact number of seedlings that will emerge in a stand in the field or how long a seed lot will be able to maintain " $\mathrm{x}$ " percentage germination during storage for " $\mathrm{n}$ " months. Therefore, the proper interpretation of test results provides information that allows the selection of better seed lots, the determination of the required quantity of seeds and its distribution during sowing, and an estimation of probable commercial success under various field conditions.

Seed vigor is the combination of characteristics that determine the potential for high performance after sowing. As a consequence, there are various techniques to determine its assessment, including those that directly or indirectly evaluate the current seed metabolic state to establish a relationship with seedling emergence and storability; those tests include (i) electrical conductivity, (ii) tetrazolium, and (iii) tests that evaluate seedling growth. In contrast, some tests are performed with the objective of identifying seed tolerance to stress(es); the more important stress tests comprise the cold test, accelerated aging, and controlled deterioration.

Studies on seed vigor from the recognition of its importance were more comprehensive in the Americas than in Europe, Asia or Oceania, probably as a result 
of greater development of the seed industry and its technological importance. For this reason, a great amount of information was provided by scientists from North America when the story of seed vigor is reported. As mentioned earlier, concepts of seed vigor were developed in the literature from 1957, and it was natural that the first comprehensive studies were produced some years later. From the 1960s, the evolution of seed vigor knowledge was worldwide, with the development of several vigor tests, improvement of procedures for the most promising tests, mainly directed at sensitivity, efficiency, and possibility of standardization. Seed vigor, since that time, is the most researched subject in Seed Technology and, with progress in standardization, some tests are now recommended with higher confidence.

The first test included in the International Rules for Seed Testing of ISTA was the electrical conductivity test for garden peas (Pisum sativum L.) in 2001. Currently, ISTA Rules (ISTA, 2014) recommend this test for garden peas, field beans (Phaseolus vulgaris L.) and soybeans [Glycine $\max (\mathrm{L}$.) Merrill], the accelerated aging test for soybeans, the controlled deterioration test for Brassica spp. and the emergence of primary root for corn (Zea mays L.). Other methods will likely be included in the future since research activity continues in this field.

Dr. Clovis Terra Wetzel was the first scientist to produce a survey of the Brazilian technical and scientific literature about seeds. In 1972, he edited the "Seed Bibliographic List" comprising 1,158 references, but only six were on seed vigor (Wetzel, 1972a). Most references dealt with to field crops, with less effort given to vegetable, fruit, forage and forest seeds. The continuity of this survey was provided by the initiative of Menezes and colleagues in the 1980s. Volumes I to IV of the Brazilian Seed Bibliography were published from 1980 to 1983, respectively, including 75 references on vigor effects and evaluation over 15 years of research (Menezes et al., 1980). Currently, this 15-year value is significantly lower than what is published annually by Brazilian scientists dedicated to these topics.

The Brazilian contribution to the assessment of seed vigor was initiated at the end of the 1960s, with the return to the country of seed scientists after performing specialization programs abroad, specifically at Mississippi State University (MSU) in the USA, working in cooperation with the group headed by Dr. James C. Delouche. Those involved in these cooperative programs encouraged, mentored, and trained new students and scientists in this field. Through the 1970s, there was increased interaction with MSU, and from the early 1980's a strong collaboration of Brazilian researchers occurred with The Ohio State University under the leadership of Dr. Miller McDonald and with the University of Kentucky in association with Dr. Dennis TeKrony and Dr. Dennis Egli.

These initiatives promoted significant improvements in Brazilian competence in seeds that is now internationally recognized as reflected by the increasing number of papers published in refereed scientific journals as well as the quality enhancement of those edited in Brazil. As an example, Brazilian scientists actively participated in the third edition of the Seed Vigor Testing Handbook published by the Association of Official Seed Analysts (AOSA), the leading publication on the subject, one of them as co-editor and three responsible for specific chapters (Baalbaki et al., 2009).

\section{Cold Test}

The cold test is considered the oldest vigor test method and probably the most popular used for seed vigor assessment in the United States. It is the primary test for the hybrid corn universal seed industry, but may be also used for other species such as barley (Hordeum vulgare L.), carrot (Daucus carota L.), cotton, eggplant (Solanum melongena L.), field beans, lettuce (Lactuca sativa L.), onion (Allium cepa L.), rice (Oryza sativa L.), sorghum (Sorghum bicolor L.), soybeans, and others.

The cold test originated from the need to estimate seedling emergence with a more sensitive procedure than the standard germination test. For this reason, it is not surprising that a test including soil as a component of substrate to estimate seedling emergence was the first vigor test regularly used by corn seed industry.

The procedure has the objective of evaluate the response of seed samples subjected to a combination of low temperature, high substrate water content and, if possible, presence of pathogens. Two types of stress prevail in this test: (i) suboptimal temperature favors leakage of cell solutes during seed water uptake due to the disorganized configuration of the membrane systems. In such situation, membrane repair is relatively slow, increasing the release of leachates, including sugars; and (ii) presence of microorganisms when the substrate includes soil is increased not only as a consequence of the exposure to low temperature but also stimulated by the release of sugars so that damage to seed performance is enhanced.

These conditions contribute to a reduction in the speed and percentage germination or seedling emergence, depending on the procedure adopted to conduct the test. Consequently, the vigor of a seed lot is proportional to the degree of seed survival when exposed to such an unfavorable environment.

Dickson and Holbert (1926) reported a procedure to study the seedling infection mechanism by Giberella cyanogena using soil as substrate; this protocol was adopted to differentiate seed lots according to physiological potential (Baalbaki et al., 2009). Afterwards, based on these previous observations, Alberts (1927) developed a test to evaluate the efficiency of fungicides after sowing in a cold and humid media and this procedure is considered the precursor of the cold test. Since the 1940s, this test has become routinely used in seed quality control programs by hybrid corn seed companies in North America (Tatum and Zuber, 1943; Pinnel, 1949; Hoppe, 1951; Moore and Goodsell, 
1965), but only from 1976 did this test receive more attention from European scientists and seed companies (TeKrony, 1983).

The cold test was studied for the first time in Brazil by Toledo (1966) using a rolled towel procedure proposed by Hoppe (1951) to assess cotton (Gossypium hirsutum L.) seed vigor. The cold test was used a few years later by Zink (1970) to assess corn seed vigor. Other researchers started to perform cold tests, using different procedures, specially the tray method (Caseiro and Marcos-Filho, 2000). As a result, this test is widely used today in the country, primarily for corn seed quality control programs.

\section{Accelerated Aging}

The accelerated aging test (AA) provides valuable information on storage and seedling field emergence potentials. Seeds are hydrated to a specific level when exposed to relatively high temperature $\left(40\right.$ to $45^{\circ} \mathrm{C}$, usually $41{ }^{\circ} \mathrm{C}$ ) and humidity (around $100 \%$ Relative Humidity - RH) Following this aging treatment, seeds are subjected to a germination test and higher vigor seed lots tolerate this aging condition better than lower vigor seed lots and produce a higher percentage of normal seedlings (Baalbaki et al., 2009).

The development of the accelerated aging test came from observations by Crocker and Groves (1915), which suggested seed deterioration during storage was caused by protein coagulation and that this process was accelerated by increases in seed mass temperature. They suggested testing for germination after exposing seeds to temperatures from $50{ }^{\circ} \mathrm{C}$ to $100{ }^{\circ} \mathrm{C}$ for relatively short periods to estimate the storability of seed lots. Helmer et al. (1962) reported that seed responses to temperatures between $35^{\circ} \mathrm{C}$ and $40^{\circ} \mathrm{C}$ and $100 \% \mathrm{RH}$ were closely associated with clover seed vigor and suggested that this accelerated or rapid aging could be useful to evaluate seed vigor and storage potential.

The progress of these studies led to a proposal of a protocol to perform an accelerated aging test for seeds of different species to attain the objectives emphasized by Helmer et al. (1962). Delouche and Baskin (1973) later improved the methodology, but the currently recommended protocol to perform the traditional AA was developed by McDonald and Phannendranath (1978).

The AA test is performed at $41{ }^{\circ} \mathrm{C}$ because this is the maximum temperature tolerated by hydrated proteins (water content from $26 \%$ to $30 \% \mathrm{fw}$ in soybean seeds). Higher temperatures instead of causing stress can promote protein denaturation and seed death, so that use of temperatures between $43{ }^{\circ} \mathrm{C}$ and $45{ }^{\circ} \mathrm{C}$ for seed aging usually causes a complete metabolic inactivation, especially on less vigorous seeds of some species.

The test soon came into use as a vigor test (Woodstock, 1976) and its standardization capability was emphasized by several seed technologists during the 1970s. From that, the use of the AA test continued to increase until it became one of the most globally recognized tests to evaluate seed vigor of numerous species.
The introduction and use of the AA test in Brazil occurred close to the time of its development in the USA. The first research was conducted by Toledo (1966) and the "rapid aging" test was considered a promising procedure to assess cotton seed vigor. Subsequently, Abrahão and Toledo (1969) concluded the same for field beans and Zink (1970) for corn seeds. As a consequence, more test details emerged from additional studies about AA such as those performed by Wetzel (1972b) and Krzyzanowski (1974), in addition to the significant increase in research and its increasing utilization over time, making the AA test one the most widely used in Brazil in addition to tetrazolium.

The accelerated aging test assesses seed vigor of various species, but results for vegetable seeds and other small-seeded crops sometimes are not successful because small seeds absorb water more rapidly resulting in a large variation in seed water content and lack of uniformity among seed samples (Powell, 1995). These problems promote large differences in deterioration rate and a reduction of germination after the artificial aging.

Based on these facts, Jianhua and McDonald (1996) proposed the saturated salt accelerated aging (SSAA) test that uses the same equipment and procedure as the standard accelerated aging test except for a substitution of water for a saturated salt solution (usually $\mathrm{NaCl}$ ). The first results obtained at The Ohio State University seed laboratory with Impatiens seeds showed reduction in the rates of water uptake and seed deterioration and additional advantages of simplicity and discouragement of growth of microorganisms that represent a concern in a traditional accelerated aging test.

Because the SSAA test promotes a moderate increase in seed water content at high temperatures, it has been suggested that this method is more similar to "natural aging" of seeds in contrast to the traditional AA procedure. SSAA has been intensely used in Brazil to test several species such as bell pepper (Capsicum anuum, L.), broccoli (Brassica oleracea var. italica), carrot, cauliflower (Brassica oleracea var. botrytis), corn, cucumber (Cucumis sativus), eggplant, lentil (Lens esculentus L.), lettuce, melon (Cucumis melo L.), oat (Avena sativa L.), onion, pumpkin (Cucurbita pepo L.), radish (Raphanus sativus L.), spinach (Spinacea pçeracea L.), soybeans, sugar beet (Beta vulsgaris L.), sweet corn. tomato (Solanum lycopersicum L.), wheat (Triticum aestivum L.), as reported by Marcos-Filho (2015) .

\section{Electrical Conductivity}

Together with the tetrazolium test, the electrical conductivity (EC) test is classified as a biochemical test. The principle of the EC test was first proposed by Fick and Hibbard (1925), associating low germinability of timothy seeds to the high release of solutes during hydration. Later, Priestley (1958) found that the electrical conductivity of cotton seed soaking solution was inversely proportional to germination, but until that time there was no mention of this analysis with possible evaluation 
of seed vigor. This idea was developed by Matthews and Bradnock (1967), who proposed a detailed methodology for this test, establishing a basic procedure to estimate the percentage of seedling emergence in peas, then widely disseminated for use in various species.

The principle of the EC test is that less vigorous or more deteriorated seeds show a lower speed of cell membrane repair during seed water uptake for germination and therefore release greater amounts of solutes to the external environment. The loss of leachate includes sugars, amino acids, fatty acids, proteins, enzymes, and inorganic ions $\left(\mathrm{K}^{+}, \mathrm{Ca}^{+2}, \mathrm{Mg}^{+2}, \mathrm{Na}^{+}, \mathrm{Mn}^{+2}\right)$ and the test evaluates the amount of ion leakage. Under field conditions, leakage of exudates after sowing, reflecting the loss of cell membrane organization and selective permeability, can stimulate the growth of pathogenic microorganisms and impair seedling emergence. Ching and Schoolcraft (1968) confirmed that the increase of leakage during seed imbibition was directly related to the disruption of cell membrane systems and loss of control of permeability.

The use of the EC test to assess seed vigor increased over time, first in Europe and USA as demonstrated by studies by Heydecker, (1969), Gill and Delouche (1973), and Loeffler et al. (1988). In the meantime, probably the first reference of the EC test in Brazil was from MarcosFilho et al. $(1985,1986)$ working with soybeans and sunflower, respectively, followed by many others from that date (Marcos-Filho, 2015), making this test widely used in research programs on seed vigor testing.

\section{Tetrazolium}

Tetrazolium is a rapid test to estimate seed viability and vigor based on color alterations of seed living tissues in contact with a solution of 2,3,5 triphenyl tetrazolium chloride, thus reflecting the degree of activity of the dehydrogenase enzyme system closely related to seed respiration and viability.

In the early $20^{\text {th }}$ century, as reported by FrançaNeto and Krzyzanowski (2009), seed technologists began developing more rapid and accurate methods for estimating seed physiological quality. Many of those methods relied on specific seed characteristics such as color, appearance, volumetric weight, rate of imbibition, electrical conductivity, and respiration heat to estimate seed viability. Moore (1969) emphasized that the first successful attempts to evaluate seed viability by vital stains were accomplished by Turina in Yugoslavia in 1922 and by Neljubow in Russia in 1925. In 1950, Lakon proposed the differentiation of high and low vigor seeds based on the location and extent of color as well as appearance of staining and tissue texture. According to França-Neto and Krzyzanowski (2009) these same principles were used and improved by Moore and Smith (1956), who classified seeds into Class "A" (vigorous), "B" (viable but non-vigorous) and "C" (non-viable). In the 1960s, Moore proposed a classification vigor system for corn and soybean seeds in which each was assigned a soundness rating of 1 to 5 if viable, and of 6 to 8 if nonviable. The presence, location and nature of staining and the physical condition of embryo structures were used as criteria in this classification system (França-Neto and Krzyzanowski, 2009). The test was successfully used by Burris et al. (1969), Byrd and Delouche (1971), Maguire et al. (1973) and others.

The test methodology was introduced in Brazil during the 1960s, but its wider use occurred about ten years later (Pereira and Andrews, 1976). The excellent work of researchers at Embrapa Soybean (the Brazilian Soybean Research Center) since 1980 should be noted. They studied and increased knowledge of this test, significantly contributed to the improvement of procedures for the evaluation of seed vigor of this species, and promoted numerous training courses for seed technologists and analysts, which included more than 1,500 participants between 1982 and 2014. Those efforts contributed to making the tetrazolium test for soybean seed the most widely used vigor test in Brazil.

Detailed procedures for the tetrazolium test for seed vigor determination have been published for cotton (Vieira and von Pinho, 1999), peanut (Arachis hypogaea L.) (Bittencourt and Vieira, 1999), field beans (Bhéring et al., 1999), corn (Dias and Barros, 1999) and soybean (França-Neto et al., 1998). Information for tropical forage seeds is also available.

\section{Tests based on seedling growth}

The uniformity and speed of seedling emergence are important components of seed performance, thus directly affecting stand establishment. Vigorous seeds more efficiently mobilize reserves from storage tissues to the embryo axis and this capacity is reflected in seedling growth as emphasized in the first studies about seed vigor (Isely, 1957).

Different vigor tests applied to seed lots of various species have demonstrated that physiologically aged or more deteriorated seed lots have slow germination and this characteristic is observed by the increasing period from the start of water uptake to the emergence of the primary root. Delayed root protrusion is known to be one of the initial signs of deterioration after seed physiological maturity (Matthews et al., 2012). The extent of deterioration is directly proportional to the length of phase II of seed germination, i.e, the lag-phase (Matthews and Khajeh-Hosseini (2007), reflecting the longer period necessary for the action of metabolic repair mechanisms or indicating an incomplete repair. As a result, the extent of seed deterioration is directly proportional to the length of the period when metabolic repair of damage caused by deterioration takes place before germination can continue

The group of tests based on seedling performance includes first count of the germination test, speed of germination or seedling emergence, seedling growth (length or dry weight), seedling vigor classification, and more recently the emergence rate of the primary root. At least one of these tests have been included in research 
on seed vigor testing to show that the uniformity and speed of seedling development are accepted components of seed vigor.

Speed of germination is considered one of the oldest seed vigor manifestations. Rapid germination is an important component of the seed vigor concept since it usually corresponds to more rapid seedling emergence in the field. The importance of this parameter for differentiating seed lots according to physiological potential was recognized around 1909 (Toumey and Korstian, 1942). The ability of seeds to quickly germinate was one of the early attributes of seed vigor and became an important indicator of seed physiological quality as a more sensitive index of seed performance than germination percentage.

Moore (1962), Edie and Burris (1970), Pederson et al. (1993) compared this method to other vigor tests and found that speed of germination or seedling emergence as well as the first count of the standard germination test (following the same principle) provided reliable estimates of seed vigor. Different formulas were developed based on germination rates over time to measure the speed of germination; Maguire (1962) proposed the most commonly adopted statistical method.

Uniform seedling emergence is also an important component of seed vigor. Therefore, the evaluation of seedling length or seedling dry weight constitutes important vigor parameters. Qualls and Cooper (1969) ranked seed lots according to vigor differences based on the extent and rapidity in which seed reserves were mobilized during germination. Such determination was also successfully performed by Edge and Burris (1970), Gill and Delouche (1973) and many others.

Those measurements based on seedling growth were included in Brazilian seed vigor research since initial studies reported by Jacintho and Carvalho (1974), Pereira and Andrews (1976) and others. This situation has not changed over time and these measurements are also successfully used to detect potential phytotoxic effects of chemicals such as fungicides, insecticides, and plant desiccants that might affect normal growth of root and hypocotyl. Tests based on seedling are simple to perform and usually do not require special equipment besides those used for germination. This makes these tests excellent options to evaluate seed vigor in species such as forest, ornamental, native and recalcitrant seeds for which there is little information about other seed vigor tests.

\section{Perspective}

At the end of the $20^{\text {th }}$ century and the beginning of the current, in addition to many attempts to improve the level of understanding of various aspects of seed performance, new knowledge about seed vigor has come from the fields of molecular biology, biotechnology, biophysics and seed and seedling imaging analyses. These new approaches have enhanced our understanding of various aspects of seed physiology and technology, and are considered symbols of modernity that should serve as important complements to traditional seed research.

In general, in spite of the availability of specific methods for assessing seed vigor including the standardization of procedures for conducting the more recommended tests, new research opportunities exist to improve the methodology of traditional seed vigor tests. The focus is to promote test standardization, accuracy, objectivity, reduction in the time required to conduct the test and the consistency of the information provided. One of the most significant examples of this evolution is the use of computer resources for the evaluation of the seed physiological potential. There is no doubt that the utilization of computers for seed vigor assessment will increase significantly in the future, but seed and seedling imaging analyses are more than promises in seed research by associating seed morphology to its performance or by the use of computerized systems to directly evaluate seed vigor.

One of early attempts to use computer image analyses of seedlings to determine seed vigor was conducted by McCormac et al. (1990) evaluating the length of the primary root in carrot and lettuce seedlings and by Howarth and Stanwood (1993) working with lettuce and sorghum. Subsequently, Sako et al. (2001) at The Ohio State University/USA developed the automated Seed Vigor Imaging System (SVIS ${ }^{\text {}}$ ) to assess lettuce seed vigor. The image analysis was performed on scanned images of seedlings, whose parts were identified and marked by developed software. After the computer image processing, data were obtained on the length of the primary root, hypocotyl and whole seedling, ratios of root / hypocotyl and indices of vigor and uniformity of growth (Figure 4).

The SVIS ${ }^{\circledast}$ developed by Sako et al. (2001) was successfully adapted for other species such as soybeans (Hoffmaster et al., 2003; Marcos-Filho et al., 2009), corn (Otoni and McDonald, 2005; Mondo et al., 2011),

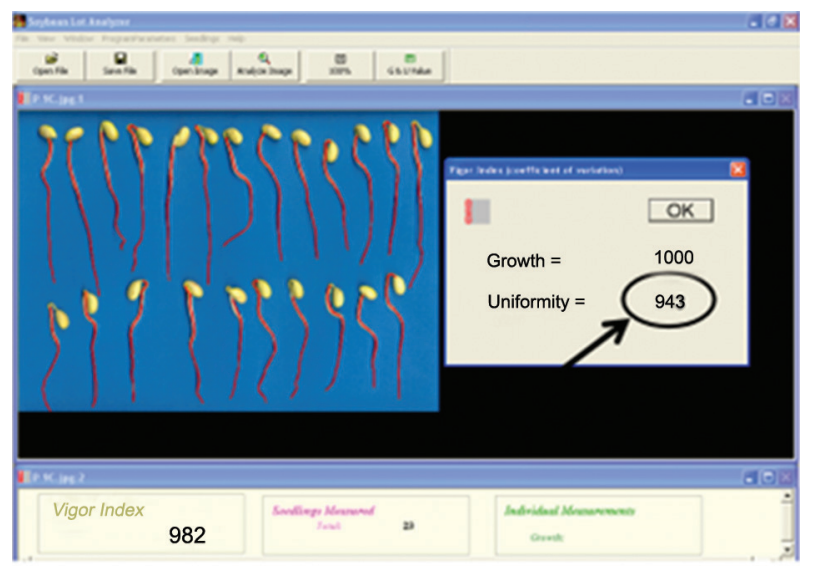

Figure 4 - Analyzed image of a soybean seedling sample by SVIS $₫$ with indications of the vigor index (982), and uniformity of seedling growth (943) (Marcos-Filho et al., 2009). 
melon (Marcos-Filho et al., 2006), cucumber (Chiquito et al., 2012), eggplant (Silva and Cicero, 2014) and others reported by Baalbaki et al. (2009) and Marcos-Filho (2015) in which the vigor index, uniformity of growth and seedling length were consistently comparable with results of recommended vigor tests.

The need to improve these procedures and the possibility of adding new computer resources to refine the analysis has motivated the development of new specific systems for the seed vigor evaluation of different species. Accordingly, the Seed Vigor Automated Analysis System (Vigor-S), a result of a collaborative program between the University of São Paulo (USP/ESALQ) and the Embrapa/Agriculture Instrumentation (CNPDIA), was designed based on similar principles to the SVIS to provide an efficient and objective evaluation of seed physiological potential (Figure 5). The possibility of obtaining consistent information on seed vigor is then enriched with consistent and dynamic alternatives since new softwares based on the principles developed by these two research groups will certainly be developed, contribute to enhance procedures and expand the diversity of options to seed analysts and technologists.

In addition to the development of research supported by image analysis tools, it has been important develop methods based on the generation or identification of new physiological markers. As emphasized by Corbineau (2012), a better understanding of cellular, molecular and biochemical mechanisms that determine the physiological seed performance has been associated with the identification of different markers such as:

- protective antioxidant mechanisms related to the activity of several enzymes such as catalase (CAT), alcohol dehydrogenase (ADH), superoxide dismutase (SOD), $\alpha$ and $\beta$ amylase, malate dehydrogenase (MDH) and others as reported by different authors among them McDonald (1999), Corbineau (2012) and Timóteo and Marcos-Filho (2013). Some of these enzymes (biochemical markers) accumulate and others have progressively reduced synthesis and activity throughout deterioration;

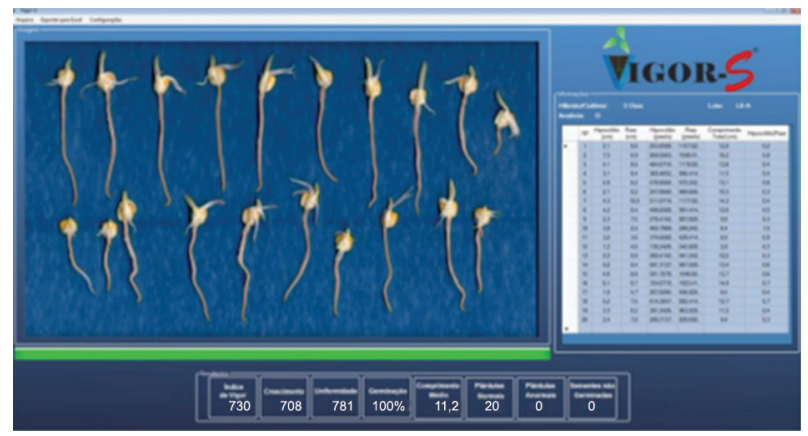

Figure 5 - Analyzed image of a corn seedling sample by Vigor-S with indications of vigor index, uniformity of seedling growth, seedling length and, on the table, coleoptile and root lengths, seedling length and a ratio of coleoptile/root length.
- variations in specific protein profiles, especially those related to respiration, lipid peroxidation and removal of free radicals could provide efficient indicators to monitor biochemical processes associated with seed vigor;

- flow cytometry has opened new possibilities for quantification of cellular events, content and integrity of DNA, critical aspects related to the normal germination process and expression of seed vigor;

- the evaluation of chlorophyll fluorescence is promising to the indirect determination of physiological potential of individual seeds by measurement of chlorophyll content (Cicero et al., 2009; Dell'Aquila, 2009); lack of degradation of this compound during seed maturation usually results negative effects on vigor.

The identification of only one marker cannot be considered sufficient to accurately assess the physiological potential of seeds in the same way that a given marker may not show the same accuracy for different species or cultivars, depending on the history of different seed lots.

Advances in molecular biology may also be employed to better assess seed physiological potential (Baalbaki et al., 2009). Some authors have suggested that the first changes in seed deterioration occur in the DNA/ RNA level leading to poor cell replication and impaired RNA translation. For example, DNA synthesis is reduced in maize seeds following accelerated aging (Cruz-Garcia et al., 1995) and this may lead to aberrant anaphases during mitosis in seedling root tips as found in seeds of different species. In addition, Matthews et al. (2012) reported that DNA ligases that repair double-stranded breaks in chromosomes and delay root protrusion have been identified; these should constitute other markers to identify declines in viability and a greater incidence of abnormal seedlings. They suggested that more research on repair in early imbibition could lead to the development of test procedures to better assess the seed physiological potential.

\section{Final comments}

The estimation of field seedling emergence is not an easy task. The results of vigor tests can be expressed in different units, and the information produced by a single vigor test is only comparative. Moreover, it is reasonable to consider that only one test cannot detect all possible facets of seed performance, since most accepted concepts of seed vigor refer to a "sum of all those properties" and not a unique characteristic. At the same time, the environment increases the degree of complexity of factors affecting seed performance. Thus, the information provided about seed vigor should be based on the interpretation of results of two or three tests whose principles might be closely related to the desired objectives. The direct influence of seed vigor on seedling establishment in the field and on 
storability justifies its inclusion in successful seed quality control programs.

Many seed companies have in-house vigor test procedures, which were studied and improved by international research around the world. The primary objective of the most recommended tests is to rank seed lots according to important differences in vigor level of commercially accepted seed lots and discard those ranked below specific minimum standards established by each seed company according to its commercial objectives and requirements of consumers.

Although many official and private seed laboratories provide vigor tests as a service, vigor parameters are still not included among the minimum standards required for commercialization. The level of knowledge about both seed vigor testing and the relationship of vigor test results with seed performance justify its consideration as a special and unique quality parameter in seed marketing and production, especially for Brazilian conditions.

The conclusions in this text had a principal purpose to provide an overview of the evolution of knowledge on seed vigor and identify the role of Brazilian seed research in advancing its importance, away from the intention to design a complete picture. This approach also attempted to highlight events that contributed to the advancement of practical knowledge in Seed Technology as well as emphasize the role of academic units in advancing seed vigor research.

\section{Acknowledgements}

To Dr. Miller McDonald, for his important suggestions to improve the quality of this text.

\section{References}

Abrahão, J.T.M.; Toledo, F.F. 1969. Preliminary results of vigor tests on bean seeds. Revista de Agricultura 44: 132, 160-163 (in Portuguese, with abstract in English).

Alberts, H.W. 1927. Effects of pericarp injury on moisture absorption, fungus attack, and viability of corn. Journal of the American Society of Agronomy 19: 1021-1030.

Association of Official Seed Analysts [AOSA]. 1983. Seed Vigor Testing Handbook. AOSA, Ithaca, NY, USA. (Contribution to the Handbook on Seed Testing, 32).

Baalbaki, R.; Elias, S.; Marcos-Filho, J.; McDonald, M.B. 2009. Seed vigor testing handbook, AOSA, Ithaca, NY, USA. (Contribution to the Handbook on Seed Testing, 32).

Basavarajappa, B.; Shetty, H.S.; Prakash, H.S. 1991. Membrane deterioration and other biochemical changes associated with accelerated ageing of maize seeds. Seed Science and Technology 19: 279-286.

Bhéring, M.C.; Silva, R.F.; Alvarenga, E.M.; Dias, D.C.F.S. 1999. Methodology of the tetrazolium test for bean seeds = Metodologia do teste de tetrazólio em sementes de feijão. p. 8.3.1 - 8.3.10. In: Krzyzanowski, F.C.; Vieira, R.D.; França-Neto, J.B., eds. Seed vigor: concepts and testing $=$ Vigor de sementes: conceitos $\mathrm{e}$ testes. ABRATES, Londrina, PR, Brazil (in Portuguese).
Bittencourt, S.R.M.; Vieira, R.D. 1999. Methodology of the tetrazolium test for peanut seeds $=$ Metodologia do teste de tetrazólio em sementes de amendoim. p. 8.2.1.-8.2.8. In: Krzyzanowski, F.C.; Vieira, R.D.; França-Neto, J.B., eds. Seed vigor: concepts and testing = Vigor de sementes: conceitos e testes. ABRATES, Londrina, PR, Brazil (in Portuguese).

Burris, J.S.; Edje, O.T.; Wahab, A.H. 1969. Evaluation of various indices of seed and seedling vigor in soybeans, Glycine $\max$ (L.) Merr. Proceedings of the Association of Official Seed Analysts 59: 73-81.

Byrd, H.W.; Delouche, J.C. 1971. Deterioration of soybean seed in storage. Proceedings of the Association of Official Seed Analysts 61: 41-57.

Caseiro, R.F.; Marcos-Filho, J. 2000. Alternative methods for evaluation of corn seed vigor by the cold test. Scientia Agricola 57: 459-466 (in Portuguese, with abstract in English).

Ching, T.M.; Schoolcraft, I. 1968. Physiological and chemical differences in aged seeds. Crop Science 8: 407-409.

Chiquito, A.A.; Gomes-Junior, F.G.; Marcos-Filho, J. 2012. Assessment of physiological potential of cucumber seeds using the software Seedling Vigor Imaging System (SVIS). Revista Brasileira de Sementes 34: 255-263.

Cicero, S.M.; van der Schoor, R.; Halink, H. 2009. Use of chlorophyll fluorescence sorting to improve soybean seed quality. Revista Brasileira de Sementes 31: 145-151.

Corbineau, F. 2012. Markers of seed quality. Seed Science Research 22: S61-S68.

Crocker, W.; Groves, J.F. 1915. A method for prophesying the life duration of seeds. Proceedings of the National Academic Sciences USA 1: 152-155.

Cruz-Garcia, F.; Gonzalez-Hernandez, V.A.; Molina-Moreno, J.; Vazquez-Ramos, J.M. 1995. Seed deterioration and respiration as related to DNA metabolism in germinating maize. Seed Science and Technology 23: 477-486.

Das, G.; Sen-Mandi, S. 1992. Triphenyl tetrazolium chloride staining pattern of differentially aged wheat seed embryos. Seed Science and Technology 20: 367-373.

Dell'Aquila, A. 2009. Development of novel techniques in conditioning, testing and sorting seed physiological quality. Seed Science and Technology 37: 608-624.

Delouche, J.C.; Baskin, C.C. 1973. Accelerated aging techniques for predicting the relative storability of seed lots. Seed Science and Technology 1: 27-452.

Delouche, J.C.; Caldwell, W.P. 1960. Seed vigor and vigor tests. Proceedings of the Association of Official Seed Analysts 50: 124-129.

Delouche, J.C.; Grabe, D.F. 1958. Seed vigor and vigor tests. The AOSA Newsletter 32: 34-37.

Dias, M.C.L.; Barros, A.S.R. 1999. Methodology of the tetrazolium test for corn seeds $=$ Metodologia do teste de tetrazólio em sementes de milho. p. 8.4.1-8.4.10. In: Krzyzanowski, F.C.; Vieira, R.D.; França-Neto, J.B., eds. Seed vigor: concepts and testing = Vigor de sementes: conceitos e testes. ABRATES, Londrina, PR, Brazil (in Portuguese).

Dickson, J.G; Holbert, J.R. 1926. Influence of the temperature upon the metabolism and expression of disease resistance in selfed lines of corn. Journal of the American Society of Agronomy 18: 314-322. 
Edje, O.T.; Burris, J.S. 1970. Seedling vigor in soybeans. Proceedings of the Association of Official Seed Analysts 60: 149-157.

Fick, G.L.; Hibbard, R.P. 1925. A method for determining seed viability by electrical conductivity measurements. Michigan Academy of Sciences, Arts and Letters 5: 95-103.

França-Neto, J.B.; Krzyzanowski, F.C.; Costa, N.P. 1998. The tetrazolium test for soybean seeds. Embrapa Soja, Londrina, PR, Brazil. (Documents, 115).

França-Neto, J.B.; Krzyzanowski, F.C. 2009. The tetrazolium test for seed vigor determination, p. 100-104. In: Baalbaki, R.; Elias, S.; Marcos-Filho, J.; McDonald, M.B., eds. Seed vigor testing handbook, OASA, Ithaca, NY, USA. (Contribution to the Handbook on Seed Testing, 32).

Franck, W.J. 1950. Introductory remarks concerning a modified working of the international rules for testing seeds on the basis of experience gained after the world war. Proceedings of the International Seed Testing Association 16: 405-430.

Ganguli, S.; Sen-Mandi, S. 1990. Some physiological differences between naturally and artificially aged wheat seeds. Seed Science and Technology 18: 507-514.

Gill, N.S.; Delouche, J.C. 1973. Deterioration of seed corn during storage. Proceedings of the Association of Official Seed Analysts 63: 35-50.

Helmer, J.D.; Delouche, J.C.; Lienhard, M. 1962. Some indices of vigor and deterioration in seed of crimson clover. Proceedings of the Association of Official Seed Analysts 52: 154-161.

Heydecker, W. 1969. The vigour of seeds: a review. Proceedings of the International Seed Testing Association 34: 201-219.

Hoffmaster, A.L.; Fujimura, K.; McDonald, M.B.; Bennett, M.A. 2003. An automated system for vigor testing three-day-old soybean seedlings. Seed Science and Technology 31: 701-713.

Hoppe, P.E. 1951. A new technique for incubation seed corn in cold soil for disease tests. Phytopathology 41: 18.

Howarth, M.S.; Stanwood, P.C. 1993. Measurement of seedling growth rate by machine vision. Transactions of American Society of Agricultural Engineering 36: 959-963.

International Seed Testing Association [ISTA]. 2014. Seed Vigour Testing. International Rules for Seed Testing, Zurich, Switzerland.

Isely, D. 1957. Vigor tests. Proceedings of Association of Official Seed Analysts 47: 176-182.

Jacintho, J.B.; Carvalho, N.M. 1974. Maturation of soybean seeds = Maturação de sementes de soja (Glycine $\max$ (L.) Merrill. Científica 1: 81-88 (in Portuguese).

Jianhua, Z.; McDonald, M.B. 1996. The saturated salt accelerated aging test for small seeded crops. Seed Science and Technology 25: 123-131.

Krzyzanowski, F.C. 1974. Accelerated aging as a vigor text for bean seeds $=$ A técnica de envelhecimento precoce na avaliação do vigor de sementes de feijoeiro. USP/ESALQ, Piracicaba, SP, Brazil. 104p. (M.S. Dissertation) (in Portuguese, with abstract in English).

Loeffler, T.M.; TeKrony, D.M.; Egli, D.B. 1988. The bulk conductivity test as an indicator of soybean seed quality. Journal of Seed Technology 12: 37-53.

Maguire, J.D. 1962. Speed of germination: aid in selection and evaluation for seedling emergence and vigor. Crop Science 2: 176-177.
Maguire, J.D.; Kropf, J.P.; Steen, K.M. 1973. Pea seed viability in relation to bleaching. Proceedings of the Association of Official Seed Analysts 63: 51-58.

Marcos-Filho, J. 2015. Seed Physiology of Cultivated Plants = Fisiologia de Sementes de Plantas Cultivadas. 2 ed. ABRATES, Londrina, PR, Brazil (in Portuguese).

Marcos-Filho, J.; Carvalho, R.V.; Cicero, S.M.; Demétrio, C.G.B. 1985. Relationship between seed quality, storability and field performance of soybean. Anais da E.S.A. "Luiz de Queiroz" 42: 195-249 (in Portuguese, with abstract in English).

Marcos-Filho, J.; Komatsu, Y.H.; Novembre, A.D.L.C.; Fratin, P.; Demétrio, C.G.B. 1986. Seed size and performance of sunflower (Helianthus annuus L.). II. Vigor. Revista Brasileira de Sementes 8: 21-32 (in Portuguese, with abstract in English).

Marcos-Filho, J; Kikuti, A.L.P.; Lima, L.B. 2009. Procedures for evaluation of soybean seed vigor, including an automated computer imaging system. Revista Brasileira de Sementes 31: 102-112 (in Portuguese, with abstract in English).

Marcos-Filho, J.; Bennett, M.A.; McDonald, M.B.; Evans, A.F.; Grassbaugh, E.M. 2006. Assessment of melon seed vigour by an automated computer imaging system compared to traditional procedures. Seed Science and Technology 34: 485-497.

Matthews, S. 1985. Physiology of seed ageing. Outlook on Agriculture 14: 89-94.

Matthews, S.; Bradnock, W.T. 1967. The detection of seed samples of wrinkle-seeded peas (Pisum sativum L.) of potentially low planting value. Proceedings of the International Seed Testing Association 32: 553-563.

Matthews, S.; Khajeh-Hosseini, M. 2007. Length of the lag period of germination and metabolic repair explain vigour differences in seed lots of maize. Seed Science and Technology 35: 200-212

Matthews, S.; Noli, E.; Demir, I.; Khajeh-Hosseini, M.; Wagner, M.H. 2012. Evaluation of seed quality: from physiology to international standardization. Seed Science Research S1: S69-S73.

McCormac, A.C.; Keffe, P.D.; Draper, R.S., 1990. Automated vigour testing of field vegetables using image analysis. Seed Science and Technology 18: 103-112.

McDonald, M.B. 1993. The history of seed vigor testing. Journal of Seed Technology 17: 93-101.

McDonald, M.B. 1999. Seed deterioration: physiology, repair and assessment. Seed Science and Technology 27: 177-237.

McDonald, M.B.; Phannendranath, B.R. 1978. A modified accelerated aging vigor test procedure. Journal of Seed Technology 3: 27-37.

Menezes, J.E.; Cavalcanti, E.C.M; Carvalho, E. R. 1980. Brazilian bibliography of seeds $=$ Bibliografia brasileira de sementes. Embrapa-DID, Brasília, DF Brazil. vol. I (in Portuguese).

Mondo, V.H.V.; Dias, M.A.N.; McDonald, M.B. 2011. Seed vigor imaging system for two-day-old corn seedling evaluation. Seed Technology 33: 191-196.

Moore, R.P. 1962. Tetrazolium as a universally acceptable quality test of viable seed. Proceedings of the International Seed Testing Association 27: 795-805.

Moore, R.P. 1969. History supporting tetrazolium seed testing. Proceedings of the International Seed Testing Association 32: 233-242. 
Moore, R.P.; Goodsell, S.F. 1965. Tetrazolium for predicting cold test performance of seed corn. Agronomy Journal 57: 489-491.

Moore, R. P.; Smith, E. 1956. Tetrazolium: a useful research tool in studying causes for seed germination difficulties. Proceedings of the Association of Seed Control 13: 15-22.

Otoni, R.R.; McDonald, M.B. 2005. Moisture and temperature effects on maize and soybean seedlings using the seed vigor imaging system. Seed Technology 27: 243-247.

Pederson, L.H.; Jorgensen, P.E.; Poulsen, I. 1993. Effect of seed vigour and dormancy on field emergence, development and grain yield of winter wheat (Triticum aestivum L.) and winter barley (Hordeum vulgare L.). Seed Science and Technology 21: 159-178.

Pereira, L.A.G.; Andrews, C.H. 1976. Comparison of vigor tests for the evaluation of soybean seed physiological quality. Semente 2: 15-25 (in Portuguese, with abstract in English).

Pinnel, E.L. 1949. Genetics and environmental factors affecting corn seed germination at low temperature. Agronomy Journal 41: 562-568.

Pollock, B.M.; Roos, E.E. 1972. Seed and seedling vigor. v.1. p. 314-388. In: Koslowski, T.T., ed. Seed biology. Academic Press, New York, NY, USA.

Powell, A.A. 1995. The controlled deterioration test. p. 73-87. In: van der Venter, H.A., ed. Seed Vigour Testing Seminar. The International Seed Testing Association, Kopenhagen, Denmark.

Priestley, J.T. 1958. Relation of protoplast permeability to cotton seed viability and predisposition to seedling disease. Plant Disease Reporter 42: 852

Priestley, D.A. 1986. Seed Aging: Implications for Seed Storage and Persistence in the Soil. Comstock, Ithaca, NY, USA.

Qualls, M.; Cooper, C.S. 1969. Germination, growth and respiration rates of birdsfoot trefoil at three temperatures during the early non-photosynthetic stage of development. Crop Science 9: 758-760.

Sako, Y.; McDonald, M.B.; Fujimura, K.; Evans, A.F.; Bennett, M.A. 2001. A system of automated seed vigour assessment. Seed Science and Technology 29: 625-636.

Sharf, A.F. 1953. Correlation of germination data of corn and soybean seed lots under laboratory, greenhouse, and filed conditions. Proceedings of the Association of Seed Analysts 43: 127-130.

Silva, V.N.; Cicero, S.M. 2014 Seedling imaging analyze to evaluate eggplant seed physiological potential. Horticultura Brasileira 32: 145-151 (in Portuguese, with abstract in English).

Stahl, C. 1931. Comparative experiments between the laboratory and the field germination of seed. Proceedings of the International Seed Testing Association 15-17: 75-143.
Tatum, L.A.; Zuber, M.S. 1943. Germination of maize under adverse conditions. Journal of the American Society of Agronomy 35: 48-59.

TeKrony, D.M. 1983. Seed vigor testing 1982. Journal of Seed Technology 8: 55-60.

TeKrony, D.M. 2003. Precision is an essential component in seed vigor testing. Seed Science and Technology 31: 435-477.

Timóteo, T.S.; Marcos-Filho, J. 2013. Seed performance of different corn genotypes during storage. Journal of Seed Science 35: 207-215.

Toledo, F.F. 1966. Comparison of methods for vigor determination of cotton seeds $=$ Revista de Agricultura 41: 13-16 (in Portuguese, with abstract in English).

Toumey, J.W.; Korstian, C.F. 1942. Seeding and Planting in the Practice of Forestry. 3ed. Wiley, New York, NY, USA.

Vieira, M.G.G.C.; Von Pinho, E.V.R. 1999. Methodology of the tetrazolium test on cotton seeds $=$ Metodologia do teste de tetrazólio em sementes de algodão, p. 8.1.1-8.1.12. In: Krzyzanowski, F.C.; Vieira, R.D.; França-Neto, J.B., eds. Vigor seeds: concepts and testing $=$ Vigor de Sementes: Conceitos e Testes. ABRATES, Londrina, PR, Brazil (in Portuguese).

Wetzel, C.T. 1972a. Seed bibliographic list = Lista bibliográfica de sementes. Fundação IBGE, Rio de Janeiro, RJ, Brazil (in Portuguese).

Wetzel, C.T. 1972b. Aging Test for Rice, Wheat and Soybean Seed Vigor Evaluation = Contribuição ao Estudo da Aplicação do Teste de Envelhecimento visando a Avaliação do Vigor de Sementes de Arroz, de Trigo e de Soja. USP/ESALQ, Piracicaba, SP, Brazil. (M.S. Dissertation) (in Portuguese, with abstract in English).

Wilson, D.O.; McDonald, M.B. 1986. The lipid peroxidation model of seed ageing. Seed Science and Technology 14: 269300 .

Woodstock, L.W. 1965. Seed vigor. Seed World 97: 6.

Woodstock, L.W. 1973. Physiological and biochemical tests for seed vigor. Seed Science and Technology 1: 127-157.

Woodstock, L.W. 1976. Progress report on the seed vigor testing handbook. Association of Official Seed Analysts Newsletter 59: 1-78.

Zink, E. 1970. Evaluation of corn seed vigor. Seminário Brasileiro de Sementes, 2. Anais... Pelotas, RS, Brazil (in Portuguese with abstract in English). 